\title{
Aquimarina macrocephali sp. nov., isolated from sediment adjacent to sperm whale carcasses
}

\author{
Correspondence \\ Yuriko Nagano \\ y.nagano@jamstec.go.jp
}

\author{
Masayuki Miyazaki, Yuriko Nagano, Yoshihiro Fujiwara, Yuji Hatada \\ and Yuichi Nogi
}

Institute of Biogeosciences (BioGeos), Japan Agency for Marine-Earth Science and Technology (JAMSTEC), 2-15 Natsushima-cho, Yokosuka 237-0061, Japan

\begin{abstract}
A Gram-negative, rod-shaped, non-spore-forming, strictly aerobic strain with gliding motility, designated JAMB $N 27^{\top}$, was isolated from sediment adjacent to sperm whale carcasses off Kagoshima, Japan, at a depth of 219 m. Strain JAMB N2 $7^{\top}$ contained MK-6 as the major isoprenoid quinone and iso- $C_{15: 0}$, iso- $C_{15: 1}, C_{16: 1}$ and iso- $C_{17: 1}$ as the predominant fatty acids. Casein, chitin, gelatin and starch were degraded. Phylogenetic analysis based on $16 \mathrm{~S}$ rRNA gene sequences showed that strain JAMB N27 $7^{\top}$ represented a separate lineage within the genus Aquimarina. The DNA G $+\mathrm{C}$ content of strain JAMB N27 ${ }^{\top}$ was $33.1 \mathrm{~mol} \%$. DNA-DNA relatedness values between strain JAMB N27 $7^{\top}$ and type strains of species of the genus Aquimarina were significantly lower than the cut-off value accepted for the definition of a novel species. Therefore, strain JAMB N2 $7^{\top}$ represents a novel species, for which the name Aquimarina macrocephali sp. nov. is proposed. The type strain is JAMB N27 $7^{\top}\left(=\mathrm{JCM} 15542^{\top}=\mathrm{NCIMB}\right.$ $\left.14508^{\top}\right)$.
\end{abstract}

The genus Aquimarina was proposed by Nedashkovskaya et al. (2005) for a Gram-negative, heterotrophic and strictly aerobic bacterium with gliding motility, Aquimarina muelleri, belonging to the family Flavobacteriaceae. The species Stanierella latercula (Lewin, 1969; Reichenbach, 1989; Nedashkovskaya et al., 2005) and Gaetbulimicrobium brevivitae (Yoon et al., 2006) were reported to be neighbours of the genus Aquimarina and were reclassified into this genus, on the basis of $16 \mathrm{~S}$ rRNA gene sequence analysis and cellular fatty acid composition, along with a novel species, Aquimarina intermedia (Nedashkovskaya et al., 2006). Thus, four species of the genus Aquimarina have been recognized to date, all from marine environments: Aquimarina muelleri from seawater, A. latercula from the outflow of a marine aquarium, $A$. intermedia from a sea urchin and $A$. brevivitae from tidal flat sediment.

We have investigated an ecosystem of sperm whale carcasses off Kagoshima, Japan, for 3 years (Fujiwara et al., 2007). About 800 aerobic bacteria have been isolated from the sediment adjacent to the carcasses and some novel species from this ecosystem have been described (Miyazaki et al., 2008a, b, c). In this paper, we present a taxonomic study on another strain from this sediment.

Strain JAMB N27 ${ }^{\mathrm{T}}$ was collected from the marine sediment adjacent to sperm whale carcasses by an unmanned

Abbreviations: ML, maximum-likelihood; NJ, neighbour-joining.

The GenBank/EMBL/DDBJ accession number for the 16S rRNA gene sequence of strain JAMB N27 $7^{\top}$ is AB517144. remotely operated underwater vehicle, ROV HyperDolphin, off Kagoshima, Japan (cruise NT0308, dive 198; $31^{\circ} 23.865^{\prime} \mathrm{N} 129^{\circ} 58.766^{\prime} \mathrm{E}$ ) at a depth of $219 \mathrm{~m}$. Sediment samples were collected by the vehicle's manipulator and placed in the sample holder of the sterilized sampler. Samples were stored with $15 \%(\mathrm{v} / \mathrm{v})$ glycerol in liquid nitrogen. A portion of each sample was cultivated on Daigo's artificial seawater SP agar (Nihon Pharmaceutical) at $8{ }^{\circ} \mathrm{C}$ for approximately 1 month. Strain JAMB N27 ${ }^{\mathrm{T}}$ was isolated and maintained on marine agar 2216 (MA; Difco) or in marine broth 2216 (MB; Difco) at $20{ }^{\circ} \mathrm{C}$ and stored with $15 \%(\mathrm{v} / \mathrm{v})$ glycerol at $-80{ }^{\circ} \mathrm{C}$.

Unless otherwise indicated, physiological tests were performed using the procedures described by Barrow \& Feltham (1993) and Miyazaki et al. (2008c, d) with the modification of using artificial seawater $(2.75 \% \mathrm{NaCl}$, $0.07 \% \mathrm{KCl}, 0.54 \% \mathrm{MgCl}_{2} \cdot 6 \mathrm{H}_{2} \mathrm{O}, 0.68 \% \mathrm{MgSO}_{4} \cdot 7 \mathrm{H}_{2} \mathrm{O}$, $\left.0.14 \% \mathrm{CaCl}_{2} \cdot 2 \mathrm{H}_{2} \mathrm{O}, 0.02 \% \mathrm{NaHCO}_{3}\right)$. Growth at $4-40{ }^{\circ} \mathrm{C}$ was measured in $\mathrm{MB}$ for 1 week. Growth with 0-6\% (w/v) $\mathrm{NaCl}$ was measured in medium containing $0.5 \%$ peptone (Difco), $0.5 \%$ yeast extract (Difco), $0.68 \% \mathrm{MgSO}_{4} .7 \mathrm{H}_{2} \mathrm{O}$, $0.54 \% \mathrm{MgCl}_{2} \cdot 6 \mathrm{H}_{2} \mathrm{O}, 0.07 \% \mathrm{KCl}, 0.02 \% \mathrm{NaHCO}_{3}$ and $0.14 \% \mathrm{CaCl}_{2} \cdot 2 \mathrm{H}_{2} \mathrm{O}$ with the $\mathrm{pH}$ adjusted to $\mathrm{pH} 7.2$ at $20{ }^{\circ} \mathrm{C}$. Strain JAMB N27 ${ }^{\mathrm{T}}$ retained viability for about 1 week at $20{ }^{\circ} \mathrm{C}$. In addition, tests for the hydrolysis of cellulose, chitin and xylan were performed using MA containing $1 \%(\mathrm{w} / \mathrm{v})$ substrate and susceptibility tests for rifampicin $(5 \mu \mathrm{g})$ and vancomycin $(30 \mu \mathrm{g})$ were also performed. The cultural, physiological and biochemical 
characteristics of strain JAMB $N 27^{\mathrm{T}}$ are given in Table 1 and the species description.

Pigments were extracted with $3 \mathrm{ml}$ acetone/methanol $(7: 2$, $\mathrm{v} / \mathrm{v})$ per $\mathrm{g}$ wet pellet and the absorption spectra were determined at 300-700 nm with a Hitachi U-2000 spectrophotometer. Cells of strain JAMB N27 ${ }^{\mathrm{T}}$ produced orange-coloured pigments with maximum absorption at $451.2 \mathrm{~nm}$ (Table 1).

Cells of strain JAMB N27 $27^{\mathrm{T}}$ were routinely observed with an Olympus BX51 microscope. Transmission electron microscopy of negatively stained cells was conducted as described by Nogi et al. (1998). Cells from mid-exponential growth phase on $\mathrm{MA}$ at $20{ }^{\circ} \mathrm{C}$ were used for electron microscope observations (JEM-1210; JEOL). Cells of strain JAMB N27 $7^{\mathrm{T}}$ were rods, $0.4-0.6 \mu \mathrm{m}$ in width and 3.0-25.5 $\mu \mathrm{m}$ in length (Fig. 1), and motile on solid substrata by gliding.

Isoprenoid quinones were extracted with chloroform/ methanol $(2: 1, \mathrm{v} / \mathrm{v})$ from $200 \mathrm{mg}$ dried cells and purified by TLC. The purified isoprenoid quinones were analysed using reversed-phase HPLC (Komagata \& Suzuki, 1987). The major isoprenoid quinone of strain JAMB N27 $7^{\mathrm{T}}$ was MK-6.

Cellular fatty acids were extracted and analysed as described by Komagata \& Suzuki (1987). Briefly, strain JAMB $\mathrm{N} 27^{\mathrm{T}}$ was cultured in $\mathrm{MB}$ at $20{ }^{\circ} \mathrm{C}$ to midexponential growth phase and fatty acids were extracted

Table 1. Differential characteristics of strain JAMB N27 and the type strains of species of the genus Aquimarina

Strains: 1 , JAMB N27 $7^{\mathrm{T}}$; 2, A. muelleri LMG $22569^{\mathrm{T}} ; 3$, A. latercula LMG $1343^{\mathrm{T}}$; 4, A. intermedia KMM $6258^{\mathrm{T}} ; 5$, A. brevivitae SMK-19 ${ }^{\mathrm{T}}$. Data were taken from this study, Nedashkovskaya et al. (2005, 2006), Reichenbach (1989) and Yoon et al. (2006). +, Positive; -, negative; ND, no data available.

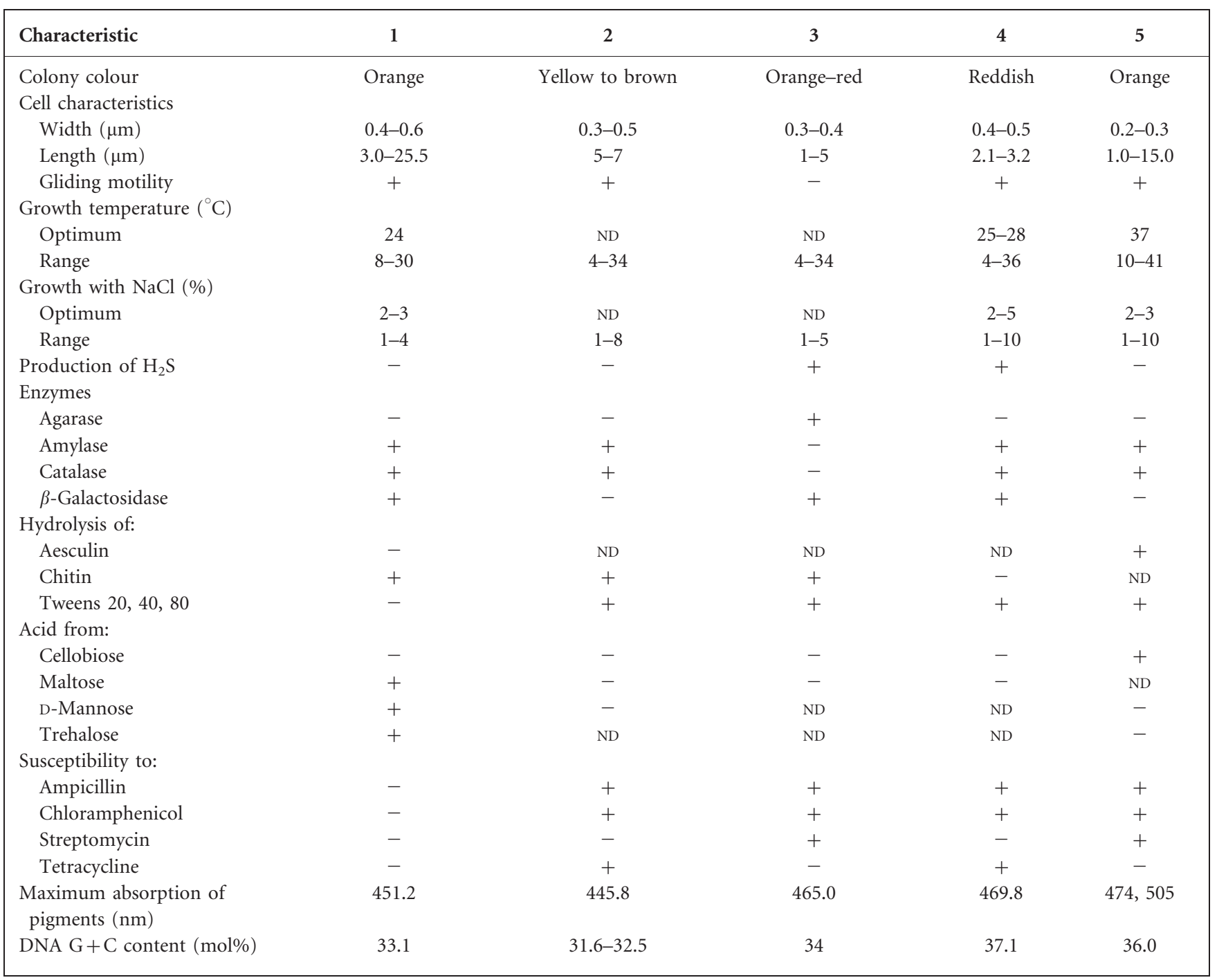



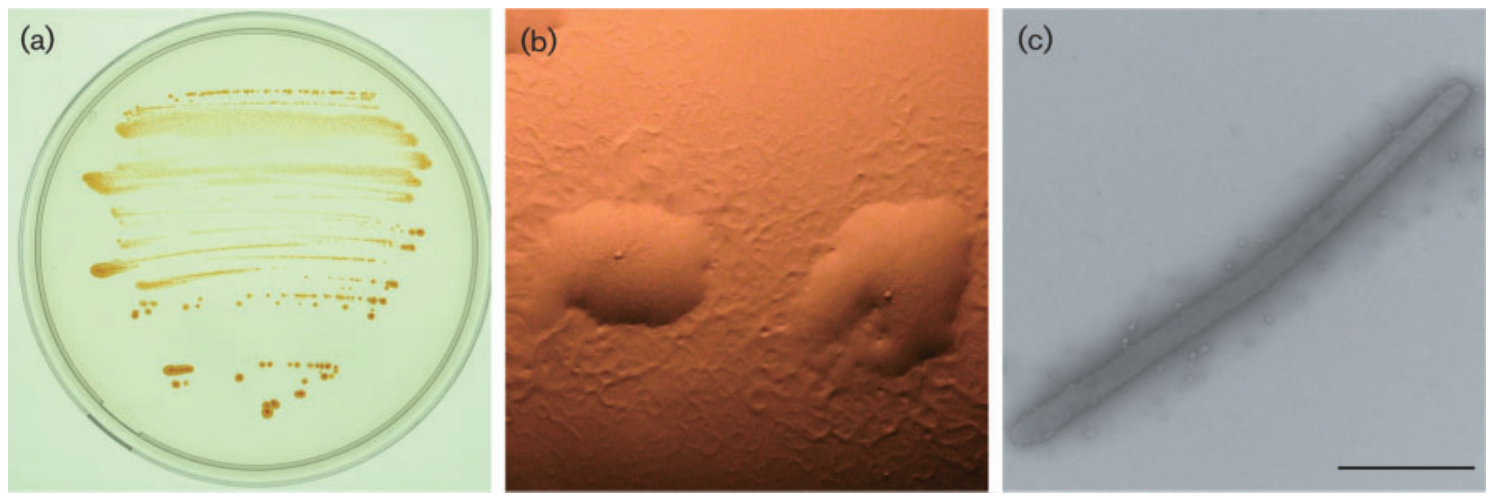

Fig. 1. Observations of colonies and cells of strain JAMB N27 ${ }^{\top}$. (a) Colonies on MA. (b) Swarm colony on Daigo's artificial seawater SP agar at 1 month. (c) Transmission electron micrograph of a negatively stained cell. Bar, $2.0 \mu \mathrm{m}$.

using the method of Miyazaki et al. (2006). The major fatty acids were iso- $\mathrm{C}_{15: 0}(32.0 \%)$, iso- $\mathrm{C}_{15: 1}(22.3 \%), \mathrm{C}_{16: 1}$ $(13.6 \%)$, iso- $\mathrm{C}_{17: 1}(10.5 \%), \mathrm{C}_{13: 0}(9.6 \%)$ and iso- $\mathrm{C}_{17: 0}$ 3-OH (5.4\%; Table 2).

Chromosomal DNA was purified using the phenol extraction method (Saito \& Miura, 1963). The DNA $\mathrm{G}+\mathrm{C}$ content was determined using reversed-phase HPLC (Tamaoka \& Komagata, 1984). DNA-DNA hybridization was performed at $38{ }^{\circ} \mathrm{C}$ for $4 \mathrm{~h}$ and DNA-DNA relatedness was measured fluorometrically using the method of Ezaki et al. (1989). The $16 \mathrm{~S}$ rRNA gene sequence of strain JAMB $\mathrm{N} 27^{\mathrm{T}}$ was obtained by direct sequencing of PCR-amplified DNA as described previously (Miyazaki et al., 2008b). The sequence was aligned with $16 \mathrm{~S}$ rRNA gene sequences obtained from GenBank by using the FastAligner utility from the ARB program (Ludwig et al., 2004) and the phylogenetic relationships of each taxon were inferred by neighbour-joining (NJ) and maximum-likelihood (ML) methods, using PAUP* 4.0 beta 10 (Swofford, 1998). NJ trees (Saitou \& Nei, 1987) were inferred from JukesCantor distances. ML trees (Felsenstein, 1981) were inferred by using the default starting parameters (NJ using a Jukes-Cantor model of evolution). Bootstrap analysis of the tree topologies was performed using 1000 and 500 replications for the $\mathrm{NJ}$ and $\mathrm{ML}$ trees, respectively.

The results of the 16S rRNA gene sequence phylogenetic analysis are shown in Fig. 2. Strain JAMB N27 $7^{\mathrm{T}}$ showed high sequence similarities with the type strains of species of the genus Aquimarina: $97.3 \%$ with A. muelleri KMM $6020^{\mathrm{T}}, 95.4 \%$ with A. latercula ATCC $23177^{\mathrm{T}}, 95.9 \%$ with A. intermedia $\mathrm{KMM} 6258^{\mathrm{T}}$ and $94.2 \%$ with A. brevivitae SMK- $19^{\mathrm{T}}$. DNA-DNA hybridization experiments showed that strain JAMB N27 $7^{\mathrm{T}}$ had less than $8.4 \%$ DNA-DNA relatedness with A. muelleri $\mathrm{KMM} 6020^{\mathrm{T}}$ and less than $1.6 \%$ DNA-DNA relatedness with A. latercula ATCC $23177^{\mathrm{T}}$. The recommended and accepted criteria for delineating bacterial species state that more than $3 \% 16 \mathrm{~S}$ rRNA gene sequence dissimilarity (Stackebrandt \& Goebel, 1994; Stackebrandt et al., 2002) and less than $70 \%$ DNA-
DNA relatedness (Wayne et al., 1987) indicate that strains belong to separate species. Thus, strain JAMB N $27^{\mathrm{T}}$ was clearly separated from the type strains of species of the genus Aquimarina according to the recommended and accepted criteria and, therefore, the strain was identified as representing a novel species.

Strain JAMB N27 $7^{\mathrm{T}}$ exhibited phenotypic features that distinguished it from the type strains of species of the genus Aquimarina (Table 1). Specifically, strain JAMB $\mathrm{N} 27^{\mathrm{T}}$ and A. muelleri KMM $6020^{\mathrm{T}}$ differed in the following characteristics: colony colour, cell dimensions, temperature and $\mathrm{NaCl}$ concentration for growth, $\beta$-galactosidase activity, hydrolysis of Tweens 20, 40 and 80 , production of acid from maltose and D-mannose, susceptibility to ampicillin, chloramphenicol and tetracycline and the maximum absorption spectra of pigments (Table 1). Moreover, the fatty acid profile showed differences with those of the reference strains (Table 2). For example, strain JAMB N27 ${ }^{\mathrm{T}}$ contained higher amounts of fatty acid iso$\mathrm{C}_{15: 1}$ and lower amounts of iso- $\mathrm{C}_{15: 0} 3-\mathrm{OH}$ and iso- $\mathrm{C}_{17: 0}$ $3-\mathrm{OH}$.

From the results of the phenotypic, genotypic and phylogenetic analyses, it is evident that strain JAMB N $27^{\mathrm{T}}$ represents a novel species within the genus Aquimarina. Therefore, we propose a novel species, Aquimarina macrocephali sp. nov.

\section{Description of Aquimarina macrocephali sp. nov.}

Aquimarina macrocephali (mac.ro.ceph'a.li. N.L. gen. n. macrocephali of macrocephalus, isolated from sediment adjacent to carcasses of Physeter macrocephalus, a sperm whale).

Cells are rod-shaped, $0.4-0.6 \mu \mathrm{m}$ in width and 3.0 $25.5 \mu \mathrm{m}$ in length. Cells are Gram-negative and motile by gliding. Colonies on MA are orange, circular, shiny with entire edges, smooth and convex, $0.5-1.0 \mathrm{~mm}$ in diameter after $2-3$ days at $20{ }^{\circ} \mathrm{C}$. Grows at 8 and $30{ }^{\circ} \mathrm{C}$ (optimum $\left.24{ }^{\circ} \mathrm{C}\right)$, but not at $32{ }^{\circ} \mathrm{C}$. Grows with $1-4 \%(\mathrm{w} / \mathrm{v}) \mathrm{NaCl}$ 
Table 2. Fatty acid compositions of strain JAMB N27 and the type strains of species of the genus Aquimarina

Strains: 1, JAMB N27 ${ }^{\mathrm{T}}$; 2, A. muelleri LMG $22569^{\mathrm{T}} ; 3$, A. latercula LMG $1343^{\mathrm{T}}$; 4, A. intermedia KMM $6258^{\mathrm{T}}$; 5 , A. brevivitae SMK $-19^{\mathrm{T}}$. Data from this study and Nedashkovskaya et al. (2006). tr, Trace $(<1.0 \%)$; - , not detected; ND, no data available.

\begin{tabular}{|c|c|c|c|c|c|}
\hline Fatty acid (\%) & 1 & 2 & 3 & 4 & 5 \\
\hline \multicolumn{6}{|l|}{ Straight-chain } \\
\hline $\mathrm{C}_{13: 0}$ & 9.6 & ND & ND & ND & $\mathrm{ND}$ \\
\hline $\mathrm{C}_{14: 0}$ & $\operatorname{tr}$ & ND & ND & $\mathrm{ND}$ & $\mathrm{ND}$ \\
\hline $\mathrm{C}_{15: 0}$ & 1.1 & 1.0 & 5.3 & 1.4 & 4.5 \\
\hline $\mathrm{C}_{16: 0}$ & 2.0 & - & - & - & 1.2 \\
\hline \multicolumn{6}{|l|}{ Unsaturated } \\
\hline $\mathrm{C}_{15: 1}$ & - & - & 1.6 & $\operatorname{tr}$ & - \\
\hline$C_{16: 1}$ & 13.6 & - & - & - & - \\
\hline $\mathrm{C}_{17: 1}$ & - & - & 1.6 & $\operatorname{tr}$ & 1.4 \\
\hline $\mathrm{C}_{18: 1}$ & - & - & - & 1.0 & - \\
\hline \multicolumn{6}{|l|}{ Branched } \\
\hline iso- $\mathrm{C}_{13: 0}$ & - & 1.5 & $\operatorname{tr}$ & $\operatorname{tr}$ & - \\
\hline iso- $\mathrm{C}_{14: 0}$ & - & - & - & - & 1.3 \\
\hline iso- $\mathrm{C}_{15: 0}$ & 32.0 & 22.2 & 18.4 & 25.9 & 20.2 \\
\hline iso- $\mathrm{C}_{15: 1}$ & 22.3 & 5.2 & 7.3 & 7.8 & 5.2 \\
\hline iso- $\mathrm{C}_{16: 0}$ & $\operatorname{tr}$ & $\operatorname{tr}$ & 2.7 & $\operatorname{tr}$ & 4.0 \\
\hline iso- $\mathrm{C}_{16: 1}$ & - & - & 1.4 & $\operatorname{tr}$ & 1.4 \\
\hline iso- $\mathrm{C}_{17: 1}$ & 10.5 & 9.9 & 4.7 & 12.7 & 3.7 \\
\hline \multicolumn{6}{|l|}{ Hydroxy } \\
\hline $\mathrm{C}_{15: 0} 2-\mathrm{OH}$ & - & - & 1.1 & - & - \\
\hline iso- $\mathrm{C}_{15: 0} 3-\mathrm{OH}$ & 1.9 & 9.7 & 7.0 & 7.0 & 6.9 \\
\hline $\mathrm{C}_{16: 0} 3-\mathrm{OH}$ & - & 1.5 & 2.0 & $\operatorname{tr}$ & - \\
\hline iso- $\mathrm{C}_{16: 0} 3-\mathrm{OH}$ & - & $\operatorname{tr}$ & 2.5 & $\operatorname{tr}$ & 2.9 \\
\hline $\mathrm{C}_{17: 0} 3-\mathrm{OH}$ & - & - & 1.1 & - & 1.0 \\
\hline iso- $\mathrm{C}_{17: 0} 3-\mathrm{OH}$ & 5.4 & 37.6 & 30.5 & 32.6 & 31.9 \\
\hline Summed feature $3 \dagger$ & - & 6.8 & 6.4 & 5.0 & 3.7 \\
\hline
\end{tabular}

$\dagger$ Summed features represent two or three fatty acids that cannot be separated by the Microbial Identification System. Summed feature 3 consisted of iso- $\mathrm{C}_{15: 0} 2-\mathrm{OH}$ and/or $\mathrm{C}_{16: 1} \omega 7$.

(optimum $2-3 \% \mathrm{NaCl}$ ), but not without $\mathrm{NaCl}$ or with $5 \%$ $\mathrm{NaCl}$. Strictly aerobic. Catalase- and cytochrome oxidasepositive. $\mathrm{H}_{2} \mathrm{~S}$ and indole are not produced. Nitrate and nitrite are not reduced. Casein, chitin, gelatin and starch are degraded. Aesculin, agar, cellulose, urea, xylose and Tweens 20, 40 and 80 are not hydrolysed. Lipase (tri-n-butyrin)

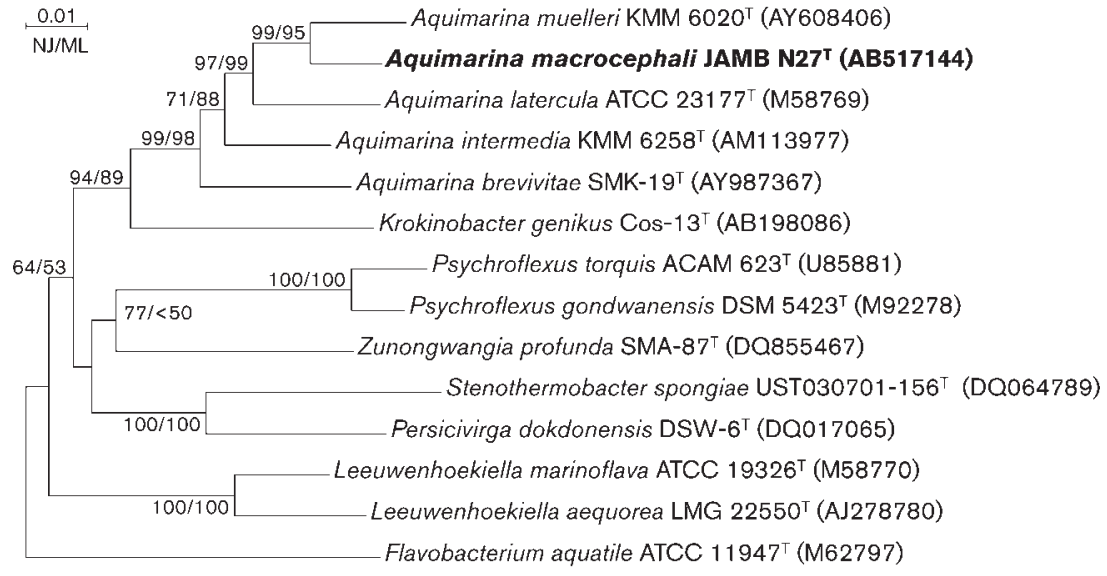

Fig. 2. $16 \mathrm{~S}$ rRNA gene sequence phylogenetic tree constructed with the $\mathrm{NJ}$ and $\mathrm{ML}$ methods showing the relationships between strain JAMB N2 $7^{\top}$ and type strains of species in the family Flavobacteriaceae. Bootstrap values ( $>50 \%$ ) based on $1000 / 500$ replicates for NJ/ML, respectively, are shown at branch nodes. Bar, 0.01 substitutions per nucleotide position. 
and $\beta$-galactosidase are produced. Acid is produced from maltose, D-mannose and trehalose, but not from Larabinose, cellobiose, D-fructose, D-galactose, D-glucose, glycerol, myo-inositol, lactose, D-mannitol, raffinose, Lrhamnose, D-sorbitol, sucrose or xylose. Susceptible to erythromycin, vancomycin and rifampicin and resistant to ampicillin, chloramphenicol, gentamicin, kanamycin, nalidixic acid, neomycin, penicillin, streptomycin and tetracycline. Produces pigment with maximum absorption at $451.2 \mathrm{~nm}$. The major isoprenoid quinone is MK-6. The dominant cellular fatty acids are iso- $\mathrm{C}_{15: 0}$, iso- $\mathrm{C}_{15: 1}, \mathrm{C}_{16: 1}$, iso- $\mathrm{C}_{17: 1}, \mathrm{C}_{13: 0}$ and iso- $\mathrm{C}_{17: 0} 3-\mathrm{OH}$.

The type strain, JAMB N27 ${ }^{\mathrm{T}}\left(=\mathrm{JCM} 15542^{\mathrm{T}}=\mathrm{NCIMB}\right.$ $14508^{\mathrm{T}}$ ), was isolated from the sediment adjacent to a sperm whale carcass off Kagoshima, Japan. The DNA G + C content of the type strain is $33.1 \mathrm{~mol} \%$ (HPLC).

\section{Acknowledgements}

We would like to thank Mr Katsuyuki Uematsu for his assistance in preparing electron micrographs. We are very grateful to the operation team of ROV Hyper-Dolphin and the crew of RV Natushima for helping with the collection of the deep-sea sediment samples.

\section{References}

Barrow, G. I. \& Feltham, R. K. A. (1993). Cowan and Steel's Manual for the Identification of Medical Bacteria, 3rd edn. New York: Cambridge University Press.

Ezaki, T., Hashimoto, Y. \& Yabuuchi, E. (1989). Fluorometric deoxyribonucleic acid-deoxyribonucleic acid hybridization in microdilution wells as an alternative to membrane filter hybridization in which radioisotopes are used to determine genetic relatedness among bacterial strains. Int J Syst Bacteriol 39, 224-229.

Felsenstein, J. (1981). Evolutionary trees from DNA sequences: a maximum likelihood approach. J Mol Evol 17, 368-376.

Fujiwara, Y., Kawato, M., Yamamoto, T., Yamanaka, T., Sato-Okoshi, W., Noda, C., Tuchida, S., Komai, T., Cubelio, S. S. \& Sasaki, T. (2007). Three-year investigations into sperm whale-fall ecosystems in Japan. Mar Ecol (Berl) 28, 219-232.

Komagata, K. \& Suzuki, K. (1987). Lipid and cell-wall analysis in bacterial systematics. Methods Microbiol 19, 161-207.

Lewin, R. A. (1969). A classification of flexibacteria. J Gen Microbiol 58, 189-206.

Ludwig, W., Strunk, O., Westram, R. \& other authors (2004). ARB: a software environment for sequence data. Nucleic Acids Res 32, 13631371.

Miyazaki, M., Nogi, Y., Usami, R. \& Horikoshi, K. (2006). Shewanella surugensis sp. nov., Shewanella kaireitica sp. nov. and Shewanella abyssi sp. nov., isolated from deep-sea sediments of Suruga Bay, Japan. Int J Syst Evol Microbiol 56, 1607-1613.

Miyazaki, M., Nogi, Y., Fujiwara, Y. \& Horikoshi, K. (2008a). Psychromonas japonica sp. nov., Psychromonas aquimarina sp. nov., Psychromonas macrocephali sp. nov. and Psychromonas ossibalaenae sp. nov.: psychrotrophic bacteria isolated from sediment adjacent to sperm whale carcasses off Kagoshima, Japan. Int J Syst Evol Microbiol 58, 1709-1714.
Miyazaki, M., Nogi, Y., Fujiwara, Y., Kawato, M., Kubokawa, K. \& Horikoshi, K. (2008b). Neptunomonas japonica sp. nov., an Osedax japonicus symbiont-like bacterium isolated from sediment adjacent to sperm whale carcasses off Kagoshima, Japan. Int J Syst Evol Microbiol 58, 866-871.

Miyazaki, M., Nogi, Y., Fujiwara, Y., Kawato, M., Nagahama, T., Kubokawa, K. \& Horikoshi, K. (2008c). Amphritea japonica sp. nov. and Amphritea balenae sp. nov., isolated from the sediment adjacent to sperm whale carcasses off Kagoshima, Japan. Int J Syst Evol Microbiol 58, 2815-2820.

Miyazaki, M., Nogi, Y., Ohta, Y., Hatada, Y., Fujiwara, Y., Ito, S. \& Horikoshi, K. (2008d). Microbulbifer agarilyticus sp. nov. and Microbulbifer thermotolerans sp. nov., agar-degrading bacteria isolated from deep-sea sediment. Int J Syst Evol Microbiol 58, 1128-1133.

Nedashkovskaya, O. I., Kim, S. B., Lysenko, A. M., Frolova, G. M., Mikhailov, V. V., Lee, K. H. \& Bae, K. S. (2005). Description of Aquimarina muelleri gen. nov., sp. nov., and proposal of the reclassification of [Cytophaga] latercula Lewin 1969 as Stanierella latercula gen. nov., comb. nov. Int J Syst Evol Microbiol 55, 225-229.

Nedashkovskaya, O. I., Vancanneyt, M., Christiaens, L., Kalinovskaya, N. I., Mikhailov, V. V. \& Swings, J. (2006). Aquimarina intermedia sp. nov., reclassification of Stanierella latercula (Lewin 1969) as Aquimarina latercula comb. nov. and Gaetbulimicrobium brevivitae Yoon et al. 2006 as Aquimarina brevivitae comb. nov. and emended description of the genus Aquimarina. Int J Syst Evol Microbiol 56, 2037-2041.

Nogi, Y., Kato, C. \& Horikoshi, K. (1998). Taxonomic studies of deepsea barophilic Shewanella strains and description of Shewanella violacea sp. nov. Arch Microbiol 170, 331-338.

Reichenbach, H. (1989). Genus I. Cytophaga Winogradsky 1929, $577,{ }^{\mathrm{AL}}$ emend. In Bergey's Manual of Systematic Bacteriology, vol. 3, pp. 2015-2050. Edited by J. T. Staley, M. P. Bryant, N. Pfennig \& J. C. Holt. Baltimore: Williams \& Wilkins.

Saito, H. \& Miura, K. (1963). Preparation of transforming deoxyribonucleic acid by phenol treatment. Biochim Biophys Acta 72, 619-629.

Saitou, N. \& Nei, M. (1987). The neighbor-joining method: a new method for reconstructing phylogenetic trees. Mol Biol Evol 4, 406425.

Stackebrandt, E. \& Goebel, B. M. (1994). Taxonomic note: a place for DNA-DNA reassociation and $16 \mathrm{~S}$ rRNA sequence analysis in the present species definition in bacteriology. Int J Syst Bacteriol 44, 846849.

Stackebrandt, E., Frederiksen, W., Garrity, G. M., Grimont, P. A. D., Kämpfer, P., Maiden, M. C. J., Nesme, X., Rossello-Mora, R., Swings, J. \& other authors (2002). Report of the ad hoc committee for the re-evaluation of the species definition in bacteriology. Int J Syst Evol Microbiol 52, 1043-1047.

Swofford, D. L. (1998). Phylogenetic analysis using parsimony (PAUP), version 4. Sunderland, MA: Sinauer Associates.

Tamaoka, J. \& Komagata, K. (1984). Determination of DNA base composition by reversed-phase high-performance liquid chromatography. FEMS Microbiol Lett 25, 125-128.

Wayne, L. G., Brenner, D. J., Colwell, R. R., Grimont, P. A. D., Kandler, O., Krichevsky, M. I., Moore, L. H., Moore, W. E. C., Murray, R. G. E. \& other authors (1987). International Committee on Systematic Bacteriology. Report of the ad hoc committee on reconciliation of approaches to bacterial systematics. Int J Syst Bacteriol 37, 463-464.

Yoon, J.-H., Kang, S.-J., Jung, S.-Y., Oh, H. W. \& Oh, T.-K. (2006). Gaetbulimicrobium brevivitae gen. nov., sp. nov., a novel member of the family Flavobacteriaceae isolated from tidal flat of the Yellow Sea in Korea. Int J Syst Evol Microbiol 56, 115-119. 